\section{Software mogul turns to mouse for genetic atlas of the brain}

Rex Dalton, San Diego

Microsoft co-founder Paul Allen is contributing \$100 million to jump-start an institute in Seattle, Washington, that will seek to unravel the genetics of the mammalian brain.

The initial project at the Allen Institute for Brain Science, which was due to be announced this week, will draw up a genetic 'brain atlas' of the mouse, as a model for studying the human brain in health and disease.

"What's exciting here is the scope of this project - to have the whole genetic map done under one set of quality controls," says Larry Katz, a neuroscientist at Duke University in Durham, North Carolina. "This will be something working neuroscientists can turn to on an ongoing basis." Katz was among many leading neuroscientists who were tapped for advice during a two-year planning process initiated by Allen.

The institute will be a non-profit organization, and aims to attract more philanthropic contributions, as well as grants from federal agencies, to support its work. About 25 of the planned 75 scientific staff have already been hired.

The mouse brain atlas will map genes that are active in various parts of the brain, in a bid to gain information on the organ's development and the functions of its neurons. Institute planners say that this will help in understanding how genes influence human behaviour, as well as identifying targets for candidate drugs to treat neurological disease.

Although many neuroscientists are already studying the genetics of the central nervous system, the institute's backers say that this will be the first attempt to map the genetics of the entire mammalian brain. Up to two-thirds of the genes in both mice and humans are believed to play a crucial role in brain development and function.

Rather than pouring money into new buildings, the institute has leased premises in Seattle and will press straight ahead with its work. Allen "is interested in going forward quickly; he didn't want to wait to build a facility", explains Mark Boguski, who will direct the brain-atlas project. Boguski is a bioinformatics expert and an original member of the National Center for Biotechnology Information.

The institute's first maps are expected to be made publicly available early next year, its managers say, with the mouse brain atlas set for completion in 2006.

\title{
California laboratory mourns loss of H-bomb pioneer
}

Jonathan Knight, Livermore

The day he died, Edward Teller had been scheduled to attend a dedication ceremony at the Lawrence Livermore National Laboratory, the nuclear-weapons research complex near San Francisco that he cofounded and inspired for half a century. The ceremony was to dedicate the Edward Teller Education Center, a collaborative effort with the University of California aimed at improving science education in California schools.

The dedication of the centre to Teller, who led the team that developed the hydrogen bomb, reflects a sense at the laboratory that Teller's public image didn't always match the true character of the physicist and teacher who died on 9 September, aged 95. (A full obituary will appear in Nature next week.)

Teller faced ostracism from many of his peers after his infamous 1954 testimony against Robert Oppenheimer, the first director of the Los Alamos National Laboratory in New Mexico and father of the atomic bomb. Questioned about whether Oppenheimer should still be allowed access to highly classified work, Teller told a congressional committee: "I feel that I would like to see the vital interests of this country in hands which I understand better, and therefore trust more."

These fateful words helped to strip Oppenheimer of his security clearance, ruining his career — and permanently alienating Teller from other physicists. "People who were his old friends and colleagues turned their backs on him," says Ray Kidder, a retired weapons scientist who worked for Teller at Livermore. In the 1980s, Teller again clashed with other physicists, forcefully advocating the Star Wars missile-defence systems proposed by President Ronald Reagan.

But last week at Livermore, those mourning Teller were stressing other aspects of his life's work. Teaching was his passion, they say, and until shortly before his death, he spent many hours at local high schools where he hoped to inspire young minds.

Teller helped to found the Livermore laboratory to develop the hydrogen bomb - an idea that many physicists, including Oppenheimer, had rejected on technical or ethical grounds. He actually directed the lab for only two years, from 1958 to 1960 - the administrative aspects of the position didn't suit him, colleagues say. But right to the end, he helped to guide the lab by maintaining close relationships with subsequent directors and senior scientists. "You always paid attention when he had a strong idea," says Bruce Tarter, who directed the lab from 1994 to 2002.

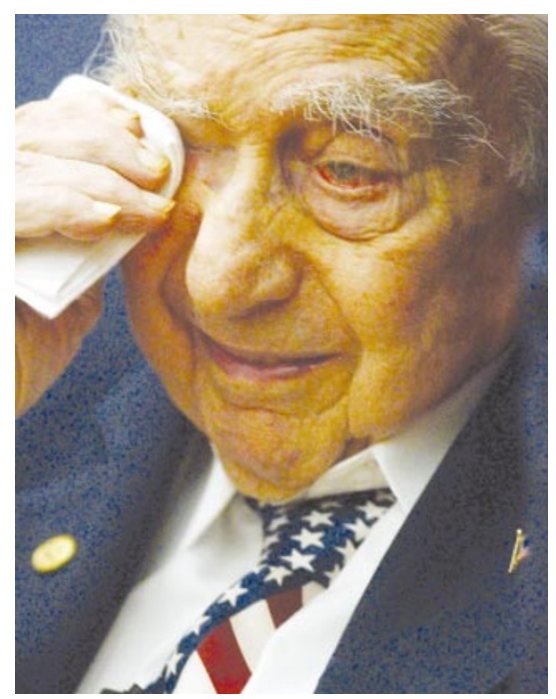

Edward Teller at Livermore last year: his influence at the lab continued to the end.

"He had so many more interesting ideas than anyone else."

Teller's collaborative spirit, dedication to critical thinking and drive to find the best solution to any given problem left a permanent impression on generations of Livermore scientists, says John Nuckolls, a protégé of Teller's and the lab's director from 1988 to 1994. "I look at this laboratory as Teller's legacy in the twenty-first century," he says.

Colleagues recall a man who was extremely focused. "Obsession is a word that comes to mind," says Marshall Rosenbluth, a student of Teller's who went on to become a leading plasma physicist. But Rosenbluth also recalls a mentor "full of charm and charisma" who was always keen to lend support — and publication credit to his students.

Kidder recalls travelling with the lab's fourth director, John Foster, for a meeting at Teller's home in Berkeley. "The mountain was coming to Mohammed," he says. "Teller stayed in the background, but he had enormous influence over what was going on."

Despite the effects of age - he used a wheelchair and his eyesight was fading Teller spent two days a week at the lab right up until the end. The week before he died he was there, discussing cosmology and nuclear physics with colleagues.

And although he will no longer roam its halls, Teller will leave an indelible mark on Livermore for years to come, Nuckolls predicts. "His personality was embedded in the lab," he says. "I have a great sense of loss, but it's going to go on."

Additional reporting by Geoff Brumfiel in Washington. 